\title{
Pride and Prejudice in South Korea's Foreign Policy
}

\author{
Koen De Ceuster
}

\begin{abstract}
On the last frontier of the Cold War, nothing is what it seems any more. On the surface, the old alliances still hold, but underneath a new order is gradually taking shape. This article analyses the various historical processes that have contributed to Seoul's redefinition of its international role. As the international political and economic context changed following the end of the Cold War in Europe, new challenges and opportunities also appeared on the horizon on the Korean peninsula. These were met by a revitalized Korean nation, where a tainted elite was gradually driven from political and economic power. Proud of its democratic institutions and content with its economic success, Seoul engages the world with dignity, looking towards the future with confidence, but sensitive over historical legacies.
\end{abstract}

\section{Of Shrimp and Whale: Reality and Its Perception}

One look at a map suffices to understand the Korean predicament. The Korean peninsula is hardly more than an appendix of the vast Asian continent. This geographical reality has had its obvious consequences on the history of Korea. Small in comparison to its three bigger neighbours, China, Russia and Japan, Korea's room for political manoeuvre has always been circumscribed by the intentions of the regional powers. At times, skilful diplomacy could hold them at bay, but on other occasions, Korea fell victim to the grand schemes of territorial aggrandisement of either China or Japan. When by the end of the 19th century modern imperialism washed up on its shores, Korea was ill-prepared to face that challenge. After several hundred years of seclusion from the world, and domestically in crisis, the Korean court failed to respond adequately. ${ }^{1}$ Korea's self-imposed international isolation disintegrated under the forceful pressure of Japan. In the wake of the 1876 unequal Kanghwado Treaty with Japan, Korea successively entered into treaty 
relations with the US, Britain, Germany, France, Russia and China. Korea's political leaders sought to maintain national sovereignty by playing off one neighbour against the other. Any skilful diplomacy was offset by the ongoing domestic politicalcrisis. During the nearly three decades between the opening of the country and colonization by Japan, Korea stumbled from one reform government to another. Political in-fighting, but above all successive political purges, left the country by the end of the 19 th century in need of visionary politicians who could both win and keep the heart of King, later Emperor, Kojong. Unable to steer a steady reform policy, the court and the country were left adrift. The resulting power vacuum on the peninsula created an international struggle for supremacy over Korea (Kim Key-Hiuk 1980; Deuchler 1977).

A traditional Korean saying has it that when whales battle, shrimps get hurt. When Japan went on the warpath over Korea, Koreans felt like the proverbial shrimp. Korea was the war bounty that Japanfought over with China (the first Sino-Japanese War, 1894-95), and with Russia (the Russo-Japanese War, 1904-05). Alongside these two military campaigns, the Japanese government sought diplomatic acquiescence from Great Britain (the Anglo-Japanese Alliance, 1905) and the US (the Taft-Katsura Agreement, 1905) for its control over Korea (Kimand Kim 1967; Duus 1995). Internationally uncontested, Korea had to endure 35 long and harsh years of Japanese colonization. No matter the suffering, Koreans failed to come up with a credible challenge to colonial rule. Liberation came as a gift, granted by the Allies when Japancapitulated on 15 August 1945.

Despite attempts to take over control of the country, Koreans were denied full independence at the time of the Japanese capitulation. The allied powers did not think the Korean people capable of managing an independent state. Their suggestion was to put Korea under international trusteeship for an indeterminate period of time, until they considered Koreans fit to govern themselves. Eventually, nothing of the sort happened. Korean demands for immediate independence and growing disenchantment between the two occupying powers (the USSR in the North, the US in the South) led to the organization of free, UN-supervised elections in the South, and the establishment of an independent Republic of Korea on 15 August 1948. The North followed suit with the establishment of the Democratic People's Republic of Korea on 9 September 1948 (Cumings1981 \& 1990). Neither state accepted the division, instead claiming legitimacy over the other half. Political posturing and military bravado eventually spilled over into outright war. 
Reminiscent of late 19th-century politics, both Korean states aptly used their international relations during the Korean War (1950-53) to further their domestic goals. The internationalization of what in essence was a domestic conflict led to a stalemate that endures through the armistice agreement until today. ${ }^{2}$ The Korean War merely confirmed the status quo ante. The Cold War regime strengthened their international alliances and allowed ideological intransigence. What resulted was a situation where both states leaned back in blissful ignorance of each other. Their positions only shifted when the security alliances of both states suffered from some strains. At such times, a strange diplomatic ballet of interKorean rapprochement started. With both sides highly self-conscious, one could hardly speak of dialogue. Inter-Korean encounters were not meant to seek an improvement of relations, nor to find solutions to pending issues, but to prove one right, and to gain the upper hand over the other. Progress was almost non-existent, and whatever slight progress was made failed to reach fruition (Gills 1996).

Europe may have been the continent where the Cold War ended, but its effects were felt globally. Along with the fall of the Berlin Wall, the containment-based stability of the post-Second World War order crumbled. Along with new opportunities, new threats appeared on the horizon. East Asia seemed largely unaffected by this groundswell of change. On the Korea peninsula, the last frontier of the Cold War formally still holds and long-standing security alliances still guarantee the status quo. Seen from a distance, it looks as if this lingering Cold War sore continues to fester, and nothing has changed in the decadeslong North-South stand-off. Visitors to the truce village, Panmunjom, come away with a vivid sense of the military tension that still reigns along the demilitarized zone. Despite the continuing military stand-off, major changes have occurred over the last 15 years on both diplomatic and political levels both in North and South Korea and in the region, changes that have not been sufficiently highlighted by the international media. This is in part due to the fact that media are event-driven, not to say crisis-driven. They are less able to pick up and decipher a gradual but incremental process of change.

The trade of global press agencies leads to short-sightedness; only the obvious, eye-catching event raises eyebrows and becomes newsworthy. The steady dynamic of change is often too subtle to be marketable, not tangible enough to be easily presentable to today's consumer, who is considered to have a short attention span. Another factor that leads to short-sightedness is the self-centredness of the media and their home 
market. Only news that directly impacts on the home constituency is deemed to be worth reporting. Foreign news tends to focus on bilateral relations and overlooks the multilateral intra-regional relations that have been evolving over the years. Since the anchor or editor speaks for the paradigmatic consumer, it is the latter's vantage point that is adopted. Asia gets hidden in a myopic blur where distance clouds distinction. The anecdotal tends to prevail. But anecdotes only thrive when existing images are confirmed over and over again. Hence news is filtered, highlighting those parts that validate the cliche, corroborating and strengthening what can only be described as an 'orientalist' gaze of an 'immutable East'. Complexity falls victim to easily digestible pieces. Even in the rare instance when local experts are asked to contribute, their input more often than not validates the prevalent image and viewpoint, leaving out or giving less prominence to any deviant views or reports. News thus tends to become a self-fulfilling prophecy (Sigal 1998: 207-28).

Commentators and political scientists seem trapped in the same mindset. Holding on to a threat-driven, security-based discourse, they tend to focus on bilateral relations, very often the relations of a specific country with the United States, and fail to capture the regional, multilateral framework of cooperation and consultation that has been taking shape over the last decades. ${ }^{3}$ Obsessed with the Cold War, and constantly reminded of it by each new crisis that erupts, they have failed to notice that these crises are nothing but the remnants of a Cold War regime. Underneath the convulsions of a bygone age, a new structure has gradually been taking shape. In the end, the Cold War lives on as a mental state more than anything else, a paradigm applied to international relations to make the world comprehensible.

This paradigm also ruled the minds of South Korean politicians. ${ }^{4}$ If the Cold War is coming to an end on the Korean peninsula, then this is not only because the international situation has changed, but also because a new generation of politicians is at the helm in Seoul. A regained awareness of agency is what makes all the difference. The unquestioned deference towards the US has been replaced by a strong sense of national dignity. The belief that the international interests of the US overlapped with South Korea's national interests has been replaced by the conviction that identical goals may hide different purposes and methods. Rather than to let the US speak for ROK interests, South Korean politicians now speak up in their own name for the interests of the whole of Korea.; The shrimp is wagging its tail. 


\section{Regional Dynamics, Nationalism and National Self-Assertion}

In the East Asian region, the end of the Cold War and the relaxation of ideological confrontation in international relations have led to a shift in the balance of power. Rather than continuing to hide behind any of the major powers, the East Asian nations stepped up their mutual dialogue and forged ahead with the construction of a new regional power equilibrium, all the while maintaining their traditional alliances (Yi 2005). In the case of the Korean peninsula, new partnerships based on mutual economic and strategic benefits emerged, gradually overruling the ideology-based alliances dating back to the Korean War. South Korea benefited most from this de-ideologization. Its economic prowess charmed both the Soviet Union and the People's Republic of China into establishing diplomatic relations with their erstwhile foe. The pragmatic foreign policy of President Roh Tae Woo lured Russia and China away from the rigidly dogmatic and confrontational foreign policies of North Korea. Nor did the North's rapid economic decline improve its international appeal.

On closer scrutiny, it becomes apparent that not only did Seoul cash in on the opportunities offered by the end of the Cold War, but there was also a domestic push factor at work. The way Seoul reacted to the changing international environment can only be understood by taking into account the momentous changes occurring at the same time within South Korean society. Rapid economic development, a peaceful democratization and a generational shift in political personnel all contributed to a marked change in the self-perception of South Koreans. The new generation at the helm seemed unburdened by the past, exuding a radiant self-confidence. As a representative and a spokesperson of this national self-confidence, the South Korean government is positioning itself internationally with greater self-assertion than ever before. At the same time, a vibrant civil society helped by a much freer press has made the government more accountable than at any time in the past (Shin 2004).

Although the affirmation of national self-assertion should be considered an aspect of an evolving Korean nationalism, I prefer to avoid this term. The lack of agreement on a common definition of nationalism on the one hand, and the frequent flippant usage of the term on the other, make this a black-box concept. Used randomly in an often undefined common-sense meaning, speakers and listeners alike project their respective cognitive and emotive biases, blurring the clarity of the 
argument. Furthermore, in a multi-disciplinary context, scholars from different disciplines bring different traditions and assumptions to the study of nationalism. Historians and political scientists talk differently about nationalism. Functional communication on such a vague and ill-defined concept as nationalism thus becomes quite hazardous. Using the less common term 'nationalself-assertion' avoids some of these pitfalls. The uncommonness of the term not only begs definition, one might also hope the reader will be more open to the specific meaning the author implies.

Admittedly, I come to 'nationalself-assertion'in an attempt to describe a political dynamic at work in South Korean society. In the social sciences, individual self-assertion presupposes the notion of individual agency within a context where the individual rights of a citizen are recognized and institutionally protected. This, in turn, implicitly suggests that the social conditions of a market economy and a liberal democracy prevail. Given these assumptions and conditions, self-assertion refers to the conscious and active engagement of an individual in a process of making claims and/or entitlements when these are not transparently or clearly defined in the organization or the system to which this individual belongs. Applying this notion to a collective level, 'national self-assertion' builds on the notion of a modern nation-state and the existence of a collective 'national'consciousness as it is expressed through strategic engagements in international affairs by the nation's representative government or by less official entities as NGOs in an attempt to affirm specific national claims and/or entitlements. ${ }^{6}$

National self-assertion, as I use it in this article, refers to a specific phase of a specific form of Korean nationalism. The historical development of Korean nationalism is a field of study in its own right. Korean nationalism has a long, but hardly uniform history. Competing forms of nationalism have confronted each other in pitched ideological battles, first over the course of Korea's struggle for national sovereignty, and later between and within rival Korean states. Not only did both Korean states use nationalism to further their popularity in the South, but the authoritarian state also confronted a popular nationalism that challenged its nationalist credentials.

South Korean state nationalism was internationally always quite subdued and rather defensive, as if Korea were a proud but frightened nation. The national self-assertion I discern in South Korea's current foreign policy is the international face of a new stage in the development of the Korean nation. ${ }^{7}$ Neither defensive, nor offensive, it is the 
expression of a democratic government that seeks to further the national interests of the Korean nation while recognizing the legitimate interests of other states. It is not the expression of a confrontational nationalism, but the illustration of a newly discovered pride and self-confidence in the viability of the Korean nation in an international environment of peaceful co-existence and co-operation with its neighbours.

\section{Tracking National Self-Assertion}

National self-assertion is the culmination of a long historical process of nation formation. In hindsight, the Korean nation awoke to the beat of modern nationalism at the end of the 19th century, but was caught in the stranglehold of Japanese colonization. It was torn apart by ideological divisions at the time of the liberation, and following the Korean War frozen into political sclerosis by Cold War intransigence.

With political culture stifled under authoritarianism, South Korean society eventually regained power over its own history through the (gradual) democratization of the state structures. The South Korean authoritarian state had attempted all along to impose its form of state nationalism, but continuously found its nationalist credentials contested. In any case, the democratization of the South Korean state lessened the importance of nationalist mobilization in support of the state. Democratically sanctioned, state legitimacy was found in popular representation, just as popular allegianceshifted to democratic institutions. In the course of the same democratization, the core component of the Korean nation, as it was implicitly understood, shifted from the political entity of the South Korean state towards a more cultural definition of an inclusive, peoplebased Korean national realm. With democracy secure in the South, the state no longer behaves in a frightened, wronged and vindictive way, but upholds an image of a confident, proud and magnanimous nation that reaches out to the world. Thus the democratization of Korean politics has led to a shift in the international position of South Korea. Driven by a strong sense of national identity and pride, the democratically elected government of the South Korean state, carried by a groundswell of popular support, advocates the interests of the Korean nation in an international context in a non-confrontational way.

Justas the Cold War was born out of Second World War, so too was the division and the foundation of two separate and ideologically opposed states on the Korean peninsula a consequence of the post-Second World War international balance of power. The division grew out of much more 
than just a security concern; it essentially shaped the political reality in the South. Political and economic development cannot be fully understood without acknowledging the depth of the division. Intellectually, the two states have quite distinct historical lineages rooted in different branches of the nationalist movement confronting Japanese colonization. This in turn relates to the development of modern nationalism in Korea from the end of the 19th century onwards.

\section{National Self-Deprecation and International Patronage}

Modern Korean nationalism developed in tandem with the historical denouement of Korean sovereignty. The concepts of modern nationalism had reached Asia along with western imperialism. Korean reformminded intellectuals acknowledged the imperialist notion that colonization was the result of the inherent weakness of the Korean nation. They opted for a wholesale surrender to western liberal ideas, an openness to the world, and recognition of world capitalism. Another more populist tradition was explicitly seclusionist in attitude, and adopted a direct and violent method. To these radical nationalists, Korean independence was an absolute and unconditional good. Confronted with the military might of Japan, however, they stood no chance. During Korea's35 years of colonial rule, the nationalist movement further splintered into various factions, covering the whole panoply from left to right, from moderate to radical, both in Korea proper and in exile. Except for some futile attempts, no unity was ever reached. Instead, ideologicalconfrontation among the various nationalist factions sapped the strength of the resistance movement, and weakened the credibility of the resistance among the Allies.

Following Japanese capitulation in 1945, fierce political battles were fought, eventually bringing to power Syngman Rhee in the South, and Kim Il Sung in the North. Although both leaders, and the states they founded, claim ancestry in the national resistance movement, Syngman Rhee belongs to the moderate nationalist lineage, whereas Kim Il Sung's nationalist pedigree is much more radical. Crowned with the aura of 'Father of the Nation',Syngman Rhee's nationalism was what Ken Wells (1990) has termed 'Christianself-reconstruction nationalism'. Intellectually, Syngman Rhee belonged to a generation of nationalists in East Asia who at the end of the 19th century interpreted international relations as a social Darwinist struggle for life among nations. He shared the conviction that the loss of independence was ultimately a consequence of the weakness of the Korean nation. 
Following the annexation, Rhee went into exile to the US, where he tirelessly worked for the cause of Korean independence. He sympathized with the plight of his supporters who stayed behind in Korea, counselling caution in opposing Japanese rule. He was no believer in armed resistance, but rather supported a gradualist course of cultural and educational edification in preparation of future independence. Rhee recognized chances for Korean independence once Japan got entangled in its war craze and started confronting the big powers. $\mathrm{He}$ trusted the big powers would eventually grant Korea its independence. Small wonder he did not blame moderate nationalists for succumbing to Japanese pressure, for losing hope, and for ending up collaborating. The 'qualified' nationalism that he shared inevitably led his followers into collaboration. After liberation, he stood by his erstwhile allies and returned them to positions of social and political dominance. The Korean colonial elite formed the core of South Korea's social elite. Despite the loudly proclaimed nationalism of the likes of Syngman Rhee and his successors as president, the South Korean elite was intellectually heir to the conviction that Korea was a weak state, and that the autonomous survival of the Korean nation was under permanent threat. They shared the political culture of 19th-century sadaejutii-the doctrine of 'servingthe Great - which made Korean rulers buy big power protection in return for political subservience. ${ }^{8}$

Following the Korean War, the main threat to South Korea was still emanating from the North. The Democratic People's Republic of Korea had lost no time in rebuilding its war-ravaged infrastructure with the help of its allies. Unlike the situation in the South, where a lot of American aid was diverted into slush funds used for buying political support, the North's centrally planned economic structure proved most effective in kick-starting the economy. The atmosphere in the South was depressed, without much hope. Given the North's proud historical roots in the armed resistance against Japanese imperialism, such reticence was utterly absent. Instead, a strong sense of historical legitimacy and an ideology of pride in what can be achieved single-handedly-the essence of North Korea's juch'e ideology-gave rise to an unflinching self-confidence.

South Korea's post-Korean War history is fundamentally shaped by the looming presence of North Korea. The willingness of the US to pump endless amounts of aid money into the South Korean economy is contextualized by South Korea's unique position as a capitalist outpost on the edge of the 'free world'. ${ }^{9}$ Behind the façade of such ideological 
sloganeering hid a quite different reality. Democracy was a farce in South Korea, always conveniently qualified and curtailed by referring to the threat North Korea posed.

Following Syngman Rhee's abdication in 1960, a 13-month democratic interlude was cut short by a coup d'etat staged by Park Chung Hee. Park is a clear example of the despots that ruled South Korea for nearly half a century. A nationalist zealot, he defended his coup by pointing out that the social turmoil that had gripped the country in the wake of Rhee's overthrow might have provoked an attack by North Korea. He also blamed corruption among politicians for the dismal state of the economy and promised that his rule would lift South Korea out of its endemic poverty into the ranks of 'civilized nations'. Like Rhee, he was nationalist with a colonial past - service in the Japanese imperial army, training at a Japanese military academy in Manchukuo-and he shared the pre-democratic nationalist tradition of 19th-century Korean intellectuals.

An enlightened nationalist, Park force-fed modernization on an unenlightened, lethargic nation. His goal was mobilization of the people for economic development, not just to win the competition with the North, but also to raise the standing of Korea in the world. Park loathed South Korea's dependency on international developmental aid, he wanted to raise the international reputation of the country. In order to do so, he mobilized the population in a program of state-controlled economic development. The message was made palatable by appealing to nationalist sentiments. He was obsessed by the idea that Korea was backward. The nation he had in mind was 'modern', where cultural superstition was replaced by rational thought, where efficiency replaced lethargy, and where steel mills and shipbuilding wharfs were the nation's pride. As a true nation builder, he was shaping a national identity, lambasting the people for their backwardness, holding out the prospect of a firstrate nation, heralding the goal of self-reliance in an economic fortress besieged by predator nations. ${ }^{10}$ Total mobilization and unquestioning obedience were the hallmarks of his regime, justified by raising the spectre of a northern threat and foreign domination. Rather than the self-confident, open nationalism that South Korea exudes today, the country was gripped by a fearful, closed nationalism. Park turned Korea into a fortress, a garrison state, where total control was imposed (Kim, Jai-Hyup 1978). The well-developed and ruthless security apparatus prevented dissenting voices from being heard; nevertheless, resistance continued to smoulder. 
Following the murder of Park Chung Hee, six months of relative freedom ensued. A care-taker president relaxed the stringent controls on society, and the demands for democratic reform resurfaced. Once again, a military intervention prevented democracy from blossoming. Chun Doo Hwan's phased coup d'etat culminating in the bloody suppression of the 1980 Kwangju Uprising pushed the genie back into the bottle. ${ }^{11}$ It would take another seven years for the opposition to muster enough support to be able to topple the authoritarian state. The memory of Kwangju lingered on, and prevented Chun from establishing true popular credibility. The shock of Kwangju was also the catalyst that strengthened the resolve of the anti-authoritarian opposition movement and allowed it to formulate an ideological critique of the authoritarian state. This led to the development during the 1980s of a counter-culture movement that undermined the legitimacy of the South Korean regime.

In the midst of such political stagnation, the South'seconomy powered ahead. The contrast with the North could not be starker. Stubbornly clinging to its juch'e ideology, the DPRK economy ground to a disastrous halt. By the time the ROK was granted membership to the OECD in 1996, the North was on an international aid lifeline. It had been deserted by its former friends and allies, its industrial base was obsolete, the agricultural sector was haemorrhaging, and to top it all, amid natural disasters and a gruesome famine, the Great Leader passed away in July 1994. With the economic gap between the two Koreas widening by the year, the threat perception from the North was sharply reduced. The South's economic development also allowed Seoul to upgrade its military capabilities, thereby reducing its dependence on the US military's technological might.

\section{Seoul to the World}

The economy may have provided the right conditions, but radical changes in the political landscape in South Korea were the trigger to a reshaping of its foreign policies. Authoritarian regimes had forced the country into rapid economic development, but a resilient society grew exasperated with authoritarianism and demanded democratic reforms. In the summer of 1987 the authoritarian state gave in to mounting public pressure by acceding to direct, free and democratic presidential elections. In retrospect, this largely cosmetic concession proved to be the start of a decade of an ever-deepening democratization of society (Saxer 2002). Through successive parliamentary and presidential elec- 
tions, the entrenched elites were gradually pushed aside, the state was reappropriated and made more accountable (Shin 2004).

The lingering legacy of backroom dealings, corruption and political bickering may not have increased popular trust in politicians in general, but support for the democratic institutions is considerable. This was quite apparent when the opposition-dominated National Assembly tried to unseat President Roh Moo Hyun by impeaching him on very slim charges in March 2004. Dubbed a 'parliamentary coup d'etat', citizens took to the streets in defence of their president and the democracy they had fought for in 1987, against the vengefulness of old-style politicians. Sensing that the achievements of the democratization struggle were challenged, the parliamentary elections of 15 April, in the midst of the impeachment imbroglio, saw a remarkable voter turnout, following years of declining participation rates in presidential and particularly parliamentary elections. The party supporting the president won a landslide victory, securing Roh Moo Hyun a majority in the National Assembly and allowing him to pursue his reform policies.

That citizens were mobilized in support of their embattled president is testimony to the vibrant civil society that has developed in the wake of political democratization. ${ }^{12}$ If democracy has deepened in South Korea, this is certainly a result of the ever-watchful eye of various civil society organizations who, in tandem with a much freer press, have made politicians more accountable for their actions. ${ }^{13}$ Building on the legacy of the anti-authoritarian political struggles of the 1980s, civil society organizations have become the hallmark of the maturing of Korean democracy. The activists who had toppled the authoritarian state resurfaced in the 1990s in various civil society movements to ensure that democratization meant more than a cosmetic institutional change (Kim, Hyŏn-Mi 2003). Covering the entire gamut of subjects from consumer interests (including environmental issues), to social and economic justice, human rights and political transparency, civil society groups critically followed the working of South Korea's democratic institutions (Kim,Hyuk-Rae 2004: 422-5). Cases of corruption and backroom dealings made a mistrustful public highly critical of the functioning of the political institutions and their personnel. It is a lasting legacy of civil society movements that they pushed the democratization of Korean society beyond the country's political institutions. NGOs saw their role in society recognized during the presidencies of Kim Dae Jung and Roh Moo Hyun, who formally integrated the civil society organizations in the institutional framework of South Korea's 'participatory democracy'. This in turn was part of 
the political project of both these presidents to sever and replace the old state-business nexus and increase the transparency of the political decision-making process (Ahn and Lee 2003). ${ }^{14}$

This development coincides with and is a result of a generational shift in Korea, both among politicians and the electorate. The so-called 386-generation-Koreansin their (late) thirties, born in the 1960s, and fighting for democracy on university campuses during the 1980s-are the ones who represent the majority vote in Korea today..$^{15}$ They are also a coveted human resources pool tapped by the administrations of both Kim Dae Jung and Roh Moo Hyun. Their obsession had never been the Korean War or the North Korean communist threat, nor poverty or destitution, but the illegitimate and politically inept regime of Chun Doo Hwan and his alleged American sponsors. More than just a political struggle, they had fought a social struggle for democracy, a fight against government-business collusion which had not only engendered a tradition of corruption, but which had also distorted economic development in favour of the large conglomerates (chaebo'l). These they viewed as bulwarks of nepotism that stifled free initiative. Just as they distrusted politicians, so too did the 386-generation doubt the chaeboll. Both were seen as a self-serving elite who pretended to speak and work for the nation, but ultimately only had their own interests at heart. Civil society organizations both held politicians accountable for their actions, and were highly critical of chaebo'l dominance of the Korean economy. The 1997 financial crisis was the watershed that finally disqualified the old generation. While the chaebŏl hung in the ropes, knocked out by the blow of the 1997 crisis, the 386-generation saw an opportunity for venture projects in IT and other businesses. Politically, Kim Dae Jung opened up the channels of power to them. Roh Moo Hyun's presidency is even more outspoken in that regard. (Kim, Pang-Hŭi 2003; Kim, Byung-Kook 2003: 236-8).

The empowerment of the people and the accountability of South Korea's political personnel have, in turn, led to a remarkable redefinition of South Korea'sinternational position. ${ }^{16}$ Following decades of submissiveness, a towering pride has taken control of Koreans. They feel proud of their peaceful democratization and secure in their economic success, both of which they realized single-handedly. Gone are the days when Koreans felt small and powerless. Gone are the days when the Korean government could cow the people into frightened submission. The struggle for (economic)survival in an unforgiving world has been won. Between the 1988 Seoul Olympics and the 2002 Soccer World Championship, Korea 
underwent a facelift from pubescent insecurity to mature adulthood. In the course of 15 years, a new generation, unburdened by the past but shouldering the historical mission of bringing North and South Korea together again, gradually invaded and undermined the old establishment. Back in 1988, Korea showcased itself to the world as a successful Asian NIC, a model of state-led rapid industrialization. By 2002, Korea had grown into one of the largest trading nations in the world, embracing globalization as an opportunity rather than a threat. The success of the 1988 Olympics had been realized under a stern authoritarian state that had workers in constant tow and held political freedom at bay. By 2002, Korea was a beacon of peaceful democratization in Asia, a nation at ease with itself, proud of its success and confident in its future.

In contrast to the Seoul Olympics, when the state led the people in a sports celebration for the world, the 2002 World Cup was carried by grassroots support. The spontaneous outburst of support for the national team during late-night rallies in front of City Hall in Seoul and across other cities in the country was an expression of this new confidence and proud self-image. Most remarkable of all was the composed, peaceful nature of the gatherings, and the absence of any animosity towards the nation's opponents (on and off the field). The positive self-image and radiating pride that imbues Koreans today, allows them to step out towards the world, magnanimously. ${ }^{17}$ Both the government, through development aid and co-operation, and the civil society, through international networking, have moved beyond the confines of Korea's borders to reach out to the region and the world. ${ }^{18}$

Economic success has allowed Korea to speak internationally with its own voice. The presidency of Kim Dae Jung-dubbed the 'NelsonMandela of Asia' because he seemed the personification of opposition against the authoritarian regimes-proved a turning point in Korea's international positioning.Coming to politics from a different background than previous presidents, and building his power on a different political constituency, Kim Dae Jungmarked the clearest break ever with Korea's post-liberation tradition. ${ }^{19}$ Confident in the strength of Korean democracy and proud of its economic success, he turned to the future rather than being bogged down by the past. ${ }^{20} \mathrm{Kim}$ Dae Jung took a bold initiative to once and for all lay the colonial past to rest and to build a strong future-oriented relationship with Japan as a close neighbour and important trading partner. At the same time, he moved to open Korea's market for Japanese (cultural) products, much to the dismay of recalcitrant anti-Japanesediehards. Kim Dae Jung's message, however, was clear. The government would no longer play off 
the anti-Japanese trump card whenever it served domestic mobilization. The president's innovative and forward-looking diplomacy contributed to a formidable change in South Korean relations with Japan, laying the lingering prejudice and grudges over Japan's political inability to atone for its colonial wrongdoings to rest. ${ }^{21}$ The success of the joint organization of the 2002 Soccer World Championships can be seen as a symbol of this new relationship.

Symbolism aside, anti-Japanese friction reappears from time to time. The Seoul government continues to express regret whenever Japanese Prime Minister Junichiro Koizumi visits the Yasukuni Shrine, but this is no longer allowed to become a stumbling block in their bilateral relations. Although the state may have compartmentalized relations with Japan so as to prevent outstanding historical friction from impeding the development of its relations with Japan, some segments in society still raise a tantrum whenever they deem that the national honour, territorial integrity, or historical legacy of Korea is being tarnished. ${ }^{22}$

Kim Dae Jung's overtures towards Japan were motivated by two concerns. As a responsible participant in a globalized world economy, unjustifiable impediments to free trade had become unacceptable. On a diplomatic level, South Korea needed Japanese support and co-operation in its audacious overtures towards North Korea. Kim Dae Junghad broken the diplomatic deadlock with North Korea and was moving doggedly beyond the imposed confines of traditional South Korean diplomacy in an attempt to open a new era of inter-Korean relations. Convinced of the sterility of the traditional confrontational strategy towards North Korea, he opted for a policy of co-operation and engagement, dubbed the 'Sunshine Policy'. The most palpable success of this approach was the summit meeting he arranged in Pyongyang with the North Korean leader Kim Jong Il in June 2000. Ever since, relations with the North have been expanding and interaction with Pyongyang increasing.

In pursuing his Sunshine Policy, Kim Dae Jung was building on the groundwork that had been laid by Roh Tae Woo's 'Nordpolitik'. What was however fundamentally different was the acknowledgement that the South did not seek the collapse or overthrow of the Northern regime. He explicitly stated that the aim of his policies was not the absorption of the North, but a gradual process of co-operation and reconciliation. He also uncoupled political progress from cultural, academic, peopleto-people and economic exchanges. It took Pyongyang nearly two years and some (financial) inducement to cast off its suspicion and finally accept his offer. ${ }^{23}$ 
Particularly interesting in respect to South Korea's changed international positioning was the fact that Kim Dae Junghad proactively sought support for his policies among South Korea's allies. Never before had a South Korean government so prominently taken the lead in engaging the North. More than ever, Seoul now decides on how to conduct interKorean relations on its own terms, and with its own interests (rather than the interests of its defence ally, the US) in mind. Whereas Kim Dae Jung publicly confirmed the continuity of the ROK-US security alliance, Roh Moo Hyun declared his adherence to the alliance, while seeking a more reciprocal and equitable relationship with the US. ${ }^{24}$ Although Washington finds it difficult to adapt to this changed Korean attitude, particularly at a time when unilateralism rules its foreign policy, it is equally clear that South Korean diplomacy is leaning heavily on the Bush administration to soften its hard-line approach towards North Korea. ${ }^{25}$ Seoul does so in tandem with its regional partners.

Convinced that Seoul's allies had to speak with one voice, Kim Dae Jung promoted the co-ordination of the North Korea policies of the US, Japan and South Korea through the creation of the Trilateral Oversight and Coordination Group in 1999. Such co-ordination serves multiple purposes. Lack of policy co-ordination had in the past led to needless friction among the allies. Suspicions flared in particular when either Japan or the US entered into direct dialogue with Pyongyang without prior consultation with Seoul. Comprehensive trilateral co-ordination was also an improvement on the traditional bilateral security dialogue that the US separately maintained with Japan and South Korea respectively. The clarity reached in such a trilateral forum also cleared the dialogue channel with Pyongyang. North Korea could no longer play off one ally against another, nor could there be any misunderstanding of what the allies had to offer to the North, both in terms of carrots and/or sticks.

Kim Dae Jung paid attention to more than Seoul'straditional security alliances which dated back to the Cold War era. In the rapidly changing security environment following the end of the Cold War, and in the context of China's increasing economy boom, Seoul sought to position itself as an active player in the region through expanding both its bilateral and multilateral contacts. In particular, Sino-Korean relations have never been so close. In a remarkable twist of history, the two former foes have turned, in little more than a decade since the establishment of diplomatic relations, into de facto allies. On the one hand, there is a clear economic imperative. China is currently Seoul's main trading partner, 
and the prime receiver of Korean FDI. On the other hand, there are also obvious diplomatic reasons behind these improved relations. As Seoul is developing a more proactive diplomacy anchored firmly in regional co-operation, it is obliged to seek Peking's co-operation. ${ }^{26}$

Seoul's diplomacy is not only driven by a strong dose of pragmatism, but also by the fundamental desire to accomplish-or at least further-the historical task of reunification of the Korean nation. Following the successful democratization of the South, the process of national rehabilitation will not be accomplished until the reunification of the nation is achieved. After wresting the state from the hands of a tainted elite, the nation now has the task of reuniting the two divided halves of the peninsula. The division was the consequence of foreign intervention, the unification will be the doing of Koreans. Politicians are well aware that a chasm looms between such fine ideals and the difficulties of bringing the two widely divergent political systems of North and South Korea closer to each other. Nonetheless, since the presidency of Kim Dae Jung, the South Korean government has persevered in its single-minded efforts to improve relations with the North. Not even the second nuclear crisis surrounding North Korea, which has been unfolding since October 2002 , is capable of derailing inter-Korean relations. Seoul stubbornly sticks to its own agenda, acknowledging along the way that the nuclear crisis needs to be solved peacefully. In pursuing this course, it finds a surprisingly willing partner in the North, as both states discover ever more common ground in their awkward mating game. Contrary to what many observers suggest, the North is not just motivated by the material benefits it gains from increased trade and investment, there is also a real and deep sense of the historical imperative for reunification.

Looking at the ongoing nuclear stand-off between North Korea and the US (and by extension the rest of the world), it is small wonder that a chasm was opening up between Washington and Seoul. While Seoul, along with Peking, wanted to see a peaceful and negotiated settlement, the Bush administration maintained an intransigent and to Pyongyang largely unacceptable position: the complete, verifiable and irreversible dismantlement (CVID) of all its nuclear programmes before the US was willing to enter in any real negotiations. ${ }^{27}$ Pressure from the other parties in the six nation negotiations certainly contributed to the fact that Washington eventually seemed to soften its stance. It was quite remarkable to see the South Korean delegation table a roadmap during the second round of talks in February 2004, which held out CVID at the end of the negotiating process, but would start with a verified 
freezing of all existing nuclear programmes (basically the status quo ante October 2002). It is towards this position that Washington moved during the third round of talks in June 2004, when the US proposed a verifiable commitment by the North to fully declare its programmes, to verifiably halt its nuclear activities, to disable its nuclear weapons, and to make preparations for the elimination of its nuclear facilities. ${ }^{28}$

Seoul counterbalances this ongoing American reluctance to engage Pyongyang by engaging its partners in the region in its efforts to induce the North out of its isolation. Despite the regularly repeated avowal of its security pledge, lingering doubts about Washington's commitment to the defence of South Korea are providing a further impetus to the nation's leaders to pay particular attention to the regional balance of power. ${ }^{29}$ Fear of American disengagement following the end of the Cold War made Seoul's strategists look towards regional multilateral security co-operation. Awakening to the need for a regional power equilibrium, Seoul now considers the solution of the Korea question within a regional context of checks and balances. The first concrete step in the direction of a regional security forum was the establishment of the ASEAN Regional Forum (ARF)in 1994. Kim Dae Jungfor his part promoted co-ordination between Japan, China and South Korea in the ASEAN Plus Three framework, and he proposed the establishment of a Northeast Asian security co-operation regime (Moon and Kim 2004: 263-4; Yi 2005). Maybe the most promising forum to date is the stalled Six Party Talks. The North Korean nuclear stalemate has brought all the strategic players in the region together. An earnest effort is underway to find a peaceful solution to this specific problem, but it might set a precedent and become a more permanent forum, not unlike the Organization for Security and Cooperation in Europe (OSCE).Though initially intended as an ad hoc response to a crisis that was dangerously spiralling out of control, this forum now has the possible bearings of a future institutionalized security co-operation and co-ordination platform, with the potential to outlast the present North Korean crisis (Yun 2005: 51-2).

\section{Conclusion}

South Korea's first and foremost foreign policy concern remains North Korea. Over the last two decades, the threat assessment of North Korea has shifted from a military towards a more comprehensive security concern. With a new generation of politicians in command, and after five years of 'sunshine'engagement on various fronts, ideological con- 
frontation has become secondary to the acknowledgement of national unity. The realization that relations with the North cannot improve in isolation, but inevitably must take place in a regional context, has caused Seoul to adopt a much more outspoken regional profile, commensurate with its economic and political standing.

At a time when an intransigent US administration is hampering Seoul's endeavour towards improved relations with the North, cracks are appearing in the traditional security alliance. Although Seoul has made it clear that it still values this security alliance and considers it crucial to the geopolitical equilibrium, it is equally firm about a much needed redefinition of the specific role each partner plays in the alliance. If cracks appear, then probably this is because the sitting administration in Washington is not sensitive enough to the feelings that reign in South Korea. Seoul is committed to contribute to the easing of tensions in the region. It does so in both bilateral and multilateral contacts with its partners in the region. Realizing that even a united Korea still moves in the shadow of its larger neighbours, it is working for a multilateral security regime where a comprehensive approach to security issues in mutual recognition and respect of national interests can be addressed.

The free direct presidential elections of December 1987 opened up a new era in the history of Korea. Since then, Koreans have again learned to speak with their own voice. Both the people and the leaders they elect defend their rightful national interests. More than just institutional democracy, they have regained an agency that they had long forgotten. Rather than stand by and watch developments unfold around it, Seoul has awoken to the challenge of shaping its own future, a future for the Korean peninsula. Seoul is determined to prove that even a shrimp, if moving shrewdly, can move among whales.

Koen De Ceuster is Associate Professor at the Centre for Korean Studies, Leiden University.

\section{NOTES}

1 The Taewbn'gun, father of the infant King Kojong (r.1864-1907) and for nearly a decade the de facto regent of Korea, was the first to face up to the crises confronting the country. Domestically, central state power was severely curtailed through bureaucratic incompetence and in-fighting, through corruption and peasant unrest, and through a dwindling revenue base. His attempts at reinvigorating the state through a comprehensive dynastic restoration clashed with institutional opposition. When in 1873 Kojong reached adulthood, the Taewbn'gun was removed from 
power, and the rigidly isolationist foreign policy was gradually abandoned (Palais 1991).

2 The Korean War has received its fair share of scholarly attention. Brune (1996) presents a good overview of the available literature. Whereas Cumings (1981 \& 1990) stresses the domestic roots of the conflict, William Stueck $(1995,2002)$ focuses more on the international ramifications of the Korean War.

3 A very good example of this style of work is the latest spate of publications on the North Korean nuclear threat and how the US should deal with it. The focus of these is almost exclusively on what US strategies should be, as if the South Korean government should have no voice in the debate over North Korea, let alone the acknowledgement of any Chinese agency in the issue. See, for example, Cha and Kang (2003) and O'Hanlon and Mochizuki (2003).

4 Prior to the end of the Cold War, international affairs were a simple thing for South Korean politicians. Surrounded by more or less inimical states, the bilateral relations with the US were of paramount importance. Cha (1999) gives an interesting analysis of how distorting and ultimately detrimental to Korea's own interests such an attitude was.

5 A telling example of this changed attitude can be found in the frankness with which South Korean President Roh Moo Hyun recently criticized the North Korea policy of the Bush administration. To make sure that his message was heard loud and clear, he used the opportunity of a speaking engagement before the World Affairs Council in Los Angeles on 12 November 2004 to vent his conviction that North Korea's security fears were legitimate and had to be addressed. Not only did he say this on American soil, but also prior to a scheduled meeting with US President George W. Bush during the APEC meeting in Santiago de Chile some days later. (Roh Moo Hyun's speeches can be found on www.korea.net).

6 I wish to acknowledge the theoreticalclarifications Michael Mau-Kuei Chang brought to our discussions in the course of the preparation of the IIAS workshop on 'Emerging National Self-Assertion in East Asia' (Amsterdam, 25 May 2004).

7 Jager (2003) offers an insight on how divergent perceptions of Korea's history lead to different attitudes to Korea's place in the world.

8 Syngman Rhee's position in Korean history has come under scrutiny recently. For a long time, he stood aloof of any criticism as Father of the Fatherland. Democratization spurred a historical revisionist movement that tried to understand the authoritarian past. As part of this revisionist reflex, Syngman Rhee's unwavering nationalism is now very much contested. One good example of this reappraisal of Syngman Rhee is Chŏng (2001). On historical revisionism, see De Ceuster (2001).

9 In 1961, the US still contributed more than 90 percent of South Korea's national budget! (Kim, Byung-Kook2003:237).For a comprehensive treatment of the US-ROK economic ties in the pre-Park Chung Hee era, see Woo (1991:45-60).

10 Park Chung Hee was moved by a near-Messianic zeal. He spared no effort to convince and mobilize the population, but also preach his revolution abroad. For a good example of this, see Park (1971).

11 Following the murder of Park Chung Hee on 26 October 1979, formal political power was taken over by the then Prime Minister Choi Kyu Ha. Chun Doo Hwan remained in the wings, first securing total control over the military, and in the course of the spring of 1980, wresting control over the political institutions by having a revised constitution accepted in a referendum. On 17 May, amid growing popular unrest, he imposed a nationwide martial law regime, suspended all political institutions, and had political and student leaders arrested. Citizens of Kwangju protested against the imposition of martial law in general and the arrest of their political hero, Kim Dae Jung. Chun 
responded to this public defiance by sending in Special Forces who went on a threeday rampage through this provincial capital. Rather than quelling the protests, this intervention led the people to storm weapons depots and drive the Special Forces out of the city. After a stand-off of nearly a week, regular army troops entered the city and ended the insurrection. The official-mortalitycount stands now at nearly 250 , a figure that remains contested. This episode forever tarnished the legitimacy of Chun Doo Hwan. The legacy of Kwangju became a rallying cry for all opposition forces against the authoritarian state (Oh 1999: 73-86; Shin and Hwang 2003).

12 No less than 551 citizen groups joined an appeal to stage rallies against the impeachment procedure following the parliamentary vote that suspended the president from duty (Na, Jeong-ju 2004).

13 The April 2000 National Assembly elections offer a good illustration of the specific role that civil society plays in South Korean society today. Despite the fact that the state has a National Election Commission to oversee campaign and elections procedures, there were doubts about its independence and effectiveness. A total of 412 citizen groups united into a Citizens' Alliance to oversee and double-check the fairness of the election campaign. They blacklisted 86 candidates who they claimed were unsuited for the job given their past (parliamentary) record. Given that 59 blacklisted candidates did not make it into the 16th National Assembly, their campaign can be considered a success (Shin, Myung-Soon 2004: 14-20). There is a downside to the proliferation of NGOs. South Korean civil society movements tend to be issue-driven, reacting to immediate causes. Institutional weakness is an inevitable consequence of such volatility (Kim, Hyuk-Rae 2004: 420).

14 Hyuk-Rae Kim (2004:421) sees a development away from 'conventional state-centric governance' paradigm towards a social governance paradigm where, in response to the authoritarian legacy of Korean politics, civil society is granted an institutionalized role thereby breaking the monopoly of parties and politicians over legislation and its enforcement.

15 Coined by the press, the 386-generation is now a common concept used in such diverse fields as political analysis, marketing and popular culture. Google Korea comes up with more than 67,000 hits when searching for 386 sedae. (www.google.co.kr, accessed on 14 March 2005). This 386-generation compares with the 5060-generation, people in their fifties/sixties, but also meaning, when read in Korean, those people identified with the Fifth (Chun Doo Hwan) and Sixth (Roh Tae Woo) Republic. In his analysis of the 2002 Presidential Election, Carl Saxer (2003)questions the often proclaimed 'generational earthquake', stressing instead the continued importance of regional voting patterns. By focusing on regionalism as an enduring factor in the 2002 elections, Saxer seems to under-estimate the developments that are appearing on the horizon. Regionalism should be qualified. Roh Moo Hyun's success in the Cholla region, which was the power base of the Millennium Democratic Party of outgoing President Kim Dae Jung, provides already a political lining to the regional voting pattern. Roh Moo Hyun has his roots in the rival city of Pusan, home ground of former President Kim Young Sam. Roh Moo Hyun, in fact, sought the MDP nomination in order to break the spell of regionalism in Korean politics (Kim, Hybn-mi 2003: 212). The regionalist voting pattern is seen here as diluted and overlapping with a clear 'opposition' or even 'anti-establishment' vote. Such 'anti-establishment' feelings have a long and well-founded tradition in Korean history, and should be taken for what they are: political attitudes. Furthermore, the demographic shift in Korean society is inevitably leading to changing voting patterns. Already during the 2002 presidential election, 48 percent of the electorate belonged to the 20-30 age bracket. While their participation in elections may not have been overwhelming 
(hoveringaround 50 percent), this generation votes more out of political motivations and convictions than any previous generation. Given the different political/historical context in which they grew up, they vote differently. As a recent poll indicated, they are at ease with a globalizing economy, they support the engagement policies towards North Korea, and have a critical attitude towards the international role of the US (Na, Sbn-mi 2005; see also Kim, Byung-Kook 2003).

16 More than any other age group, this 386-generation is marked by a strong sense of anti-Americanism, the result of a common perception that the US government condoned the suppression of the Kwangju Uprising (Kim, Byung-Kook 2003: 236-8). Chun Doo Hwan misled the Kwangju people into believing that US government had agreed to the dispatch of Special Forces to Kwangju. Despite a formal protest at the time by the US ambassador, this story was never retracted. Ever since the Kwangju Uprising, the US government has been less than forthcoming in clarifying its role at that critical time in Korean history. This attitude indirectly strengthened the perception popular among students and dissidents that the US had always been on the side of the oppressor (Oberdorfer 1997: 128-30).

17 Democratization and liberalization of the Korean economy went hand in hand. The traditionally closed economy was gradually opening up. Not only US pressure to open the domestic market, but also the desire to play a more responsible role in international trade agreements made the Korean government open to the world economy. Import barriers were gradually lifted, and Korean companies began investing in distribution and production facilities abroad. In the 1990s, South Korea also began to play a more prominent role in international politics, both globally and regionally. Furthermore, in 1988, free foreign travel was made possible by the relaxation of the rules to acquire passports. Korean citizens began spending part of their wealth on discovering the world. Finally, the press also played an important role in bringing the world to Seoul. With press restrictions lifted, international reporting in Korean media increased and improved in quality.

18 South Korea developed from an aid recipient in the 1950s to 1960s into an international aid donor in the 1990s. President Roh Tae Woo launched the Korean Overseas Volunteers (KOV) programme in 1989 and established the Korean International Cooperation Agency (KOICA) in 1991 to co-ordinate under the supervision of the Ministry of Foreign Affairs Korea's overseas development aid (see http://www. koica.go.kr/). Having been on the receiving end of international aid, Seoul is motivated by a strong sense of moral obligation to repay an international community that made the survival of South Korea possible during and after the Korean War. Hence Seoul's eagerness to contribute to international aid programmes and to play a responsible role in the UN.

19 The gradual process of democratization can be discerned by looking at the biographies of the successive presidents since 1988. Roh Tae Woo (1988-92)was Chun Doo Hwan's hand-picked candidate for president. Not only did he have a military background, but he had stood by Chun Doo Hwan in his ascension to power in 1980 . Kim Young Sam (1992-98)may have had a long parliamentary career of opposition to the authoritarian state, but he was part of the political establishment working within the boundaries set by the state. In 1990, he brokered an alliance with the government Democratic Justice Party, heir to the authoritarian state, in an attempt to strengthen his presidential bid in the 1991 elections. Although this move allowed him to reform the system from within, it is equally true that his alliance with the old elite curtailed his ability to reform the state apparatus and remove the entrenched elites. Kim Dae Jung was the first opposition candidate to win a presidential election. Despite his strategic alliance in the run-up to the election with Kim Jong Pil, 
the former right-hand man of Park Chung Hee and founder of the infamous KCIA, his was the clearest break to date with the authoritarian past. More than anything else, his political power base was utterly different from the previous governments. The financial crisis of 1997 which seemed to confirm the bankruptcy of the old boys' network of state-business collusion, allowed the incoming president to act swiftly (Gills and Gills 1999). Roh Moo Hyun's election in 2001 was another step in the deepening of democratization in Korea. With his 'new kid on the block' populist image, he rides a wave of popular support which sustains him in power over and against the distrust and disgust of the establishment.

20 In domestic politics he did so by not only granting a presidential pardon but even inviting two former presidents and past foes, Chun Doo Hwan and Roh Tae Woo, to his inauguration on 25 February 1998. During Kirn Young Sam's presidency, both Chun and Roh had faced various charges (including embezzlement and graft), and were convicted to respectively life in prison and 17 years on charges of an illegal army mutiny (the 12 December 1979 coup d'etat that opened Chun Doo Hwan's route to power) and the bloody suppression of the Kwangju Uprising.

21 During his landmark visit to Japan in August 1998, President Kirn Dae Jung came away with a remarkably upfront apology from the Japanese government. During his presidency, the import ban on Japanese cars and cultural products was lifted, and bilateral contacts were increased and diversified, including even joint military rescue operations at sea. While the South Korean government moves away from the past, the future holds new challenges. Pressure is growing in Japan to amend the peace constitution. Already, the role of the Self Defence Forces has been increased in order to respond swiftly to the new threats of the post-9/11 world order where non-state entities seem to pose graver dangers than states (Yun 2005: 21).

22 A number of outstanding issues (Japanesehistory schoolbooks, Tokdo/Takeshima, compensation for 'comfort women')cloud from time to time South Korean-Japanese relations. The South Korean government's attitude is by and large reactive, both to provocations from certain quarters in Japan, and to pressure from civil society groups in Korea itself. March 2005 saw a sudden flare-up of the Tokdo/Takeshima territorial dispute, leading to considerable diplomatic friction. In April 2005, governmental and popular dismay over the approval of revisionist history textbooks further clouded bilateral relations. Since raw emotions dominate at this stage, neither government can afford to concede. Once the dust settles and the air is clear again, the focus will shift towards the long-term policy goals of good neighbourly relations and multilateral security arrangements. Only such arrangements can contain the possible threat posed by a Japan that is moving towards amending its peace constitution and redefining the role of its Self Defence Forces (Pak 2005).

23 Kim Dae Jung announced his 'Sunshine Policy' during his inaugural speech in February 1998. Pyongyang was hesitant, but eventually got its act together. As we know now, the June 2000 summit meeting between Kirn Dae Jung and Kirn Jong Il was made more palatable to the North through a major (illegal) donation of US\$ 500 million. A major breakthrough in North-South relations came during the last weeks of Roh Tae Woo's presidency, when on 13 December 1991 both Koreas adopted an 'Agreement on Reconciliation, Nonaggression and Exchanges and Cooperation between the South and the North', followed later that same month by a North-south denuclearization agreement. Kirn Young Sam was much more sceptical about relations with the North. Following Kirn Il Sung's death in July 1994, his refusal to send condolences to the North Korean people made Pyongyang slam the door on any further governmental contact with Seoul during his presidency. Since the North was gripped by a severe food and economical crisis, Kirn Young Sam 
did not mind because he was convinced that it was only a matter of time before the North Korean regime would collapse. On the 1991 agreements and Kirn Young Sam's attitude towards the North, see Oberdorfer (1997: 260-408) and Sigal (1998) A most unflattering portrait of Kirn Young Sam is found in Wit et al. (2004). One of the reasons why Pyongyang hesitated to respond to Kirn Dae Jung's offer was initial distrust. Even in the best of circumstances, negotiations with the North are a difficult balancing act. Following Kirn Young Sam's presidency, with Pyongyang rattled by the death of Kirn Il Sung, famine and economic crisis, Kirn Jong Il may have doubted the true intentions of Kirn Dae Jung.

24 In his inaugural address on 25 February 2003, Roh Moo Hyun declared: 'This year marks the 50th anniversary of the Korea-US Alliance. It has made a significant contribution in guaranteeing our security and economic development. The Korean people are deeply grateful for this. We will foster and develop this cherished alliance. We will see to it that the alliance matures into a more reciprocal and equitable relationship. We will also expand relations with other countries, including traditional friends.' Coming on top of strong anti-American sentiments vented in the run-up to the presidential elections in December 2002, some press reports have described this demand for a more balanced and equal partnership as a lack of gratitude towards the US, going as far as to call for the withdrawal of US forces from South Korea.

25 The drifting apart of South Korea and the US is not just a consequence of the policies pursued by the Kirn Dae Jung-Roh Moo Hyun governments. A major break in US foreign policy followed the coming to power of George W. Bush. Whereas Kirn Dae Jung had found a willing partner in the Clinton administration for his Sunshine Policy, he was cold-shouldered by the incoming Bush administration in March 2001. Following 9/11, the two alliance partners drifted further apart. Obsessed with terrorism and weapons of mass destruction (WMD) proliferation, the Bush administration followed a confrontational policy towards North Korea, whereas the South Korean government persevered in its policy of engagement and co-operation. As the two governments are drifting apart, so too are the public perceptions in both countries. An April 2003 Fox News/Opinion Dynamics opinion poll in the US found that 54 percent of respondents thought North Korea posed a direct threat to the US, compared to only 10 percent for Iraq. In contrast, a January 2004 Research \& Research poll found that 39 percent of South Korean respondents felt the US posed the biggest security threat to Korea (33 percent North Korea, 12 percent China, 8 percent Japan).A 1993 Gallup poll had found 44 percent of respondents pointing to North Korea, and a mere 1 percent pointing the finger at the US (Yun 2005:13-14).

26 Seoul strategists warn of the risk that overdependence on China may revert the geopolitical equilibrium in the region to a 19th-century pattern of dependence. The chance that economic dependence on China might in the future curtail the room for political manoeuvre of the South Korean government is a real worry. It explains why South Korean diplomacy is paying so much attention to multilateral diplomacy, and why the chances for an end to the security alliance with the US remain remote (Yun2005; Yi 2005).As Korea rides a wave of national pride and steps up its international profile, some 'irredentist' mavericks in Korea are raising their voices to claim the ancient territory of Koguryd (4th to 7th centuries AD) in present Manchuria. In response, Chinese historians are involved in attempts to present Koguryd as a Chinese state. This attempt to establish the Chineseness of Koguryd can also be seen as a move to quell any illusions among the Korean minority in Manchuria about a possible incorporation into a future unified Korean state.

27 This was the attitude taken during the first round of Six Party talks in August 2003. From October 2002 until this Peking-mediated diplomatic initiative, Washington 
had been basically looking the other way, rather than to seek a direct and negotiated settlement to the ongoing crisis. The Six Party talks bring Russia, China, Japan, North and South Korea and the US to the negotiating table.

28 Twice North Korea declined to participate in a fourth round. In the run-up to the American presidential elections, it came as no surprise that Pyongyang declared it was not interested at that stage in participating in the talks. The expected February (2005)meeting did not materialize either. Instead, Pyongyang increased the pressure on Washington by officially stating that it not only possessed a nuclear weapon, but also that it felt no longer bound to adhere to its self-imposed missile test moratorium (declared in September 1999). Washington for its part seems to have shifted to a more pragmatic position, with Secretary of State Condoleeza Rice going as far as orally acknowledging North Korean sovereignty.

29 South Korean governments have often in the past been confronted with Americanfaits accomplis. The most recent examples are the unilateral announcement in June 2003 of plans for US troop redeployment away from the Demilitarized Zone (DMZ), and in June 2004 the unilateral announcement of a scheduled reduction by one-third of US troops in the South. The timetable of the reduction of US troops was extended so as to allow the South Korean armed forces sufficient time to upgrade their weaponry to compensate for this reduction in manpower.

\section{REFERENCES}

Ahn, Byung-young and Lee, Yeon-ho 2003. 'The State to Come in South Korea. Civic Engagement in Welfare and Corporate Reform in South Korea.' Paper presented at the Workshop on Globalization and Welfare Reform in China, Japan and Korea (Amsterdam School of Social Research, University of Amsterdam, 29 July).

Brune, Lester H. (ed.)1996. The Korean War. Handbook of the Literature and Research. West Port, Connecticut, and London: Greenwood Press.

Cha, Victor D.1999. Alignment despite Antagonism. The US-Korea-JapanSecurity Triangle. Stanford: Stanford University Press.

Cha, Victor D. and David C. Kang 2003. Nuclear North Korea. A Debate on Engagement Strategies. New York: Columbia University Press.

Chbng, Pyŏngjun 2001. Y i Sŭngman-ŭi tongnipnosŏn-gwa chŏngbu surip undong [Syngman Rhee's Independence Scheme and the Movement for the Foundation of a Government]. Seoul: Seoul National University (unpubl.PhD diss.).

Cumings, Bruce 1981 \& 1990. The Origins of the Korean War. (two volumes) Princeton: Princeton University Press.

De Ceuster, Koen 2001. 'The Nation Exorcised: The Historiography of Collaboration in South Korea.' Korean Studies, 25(2): 207-42.

Deuchler, Martina 1977. Confucian Gentlemen and Barbarian Envoys. The Opening of Korea, 1875-1885. Seattle and London: University of Washington Press.

Duus, Peter 1995. The Abacus and the Sword. The Japanese Penetration of Korea, 1895-1910. Berkeley, Los Angeles and London: University of California Press.

Gills, B. K. 1996. Korea versus Korea. A Case of Contested Legitimacy. London and New York: Routledge.

Gills, Barry K. and Dong-Sook S. Gills 1999. 'South Korea and Globalization: The Rise to Globalism.' Asian Perspective, 23(4): 199-228.

Jager, Sheila Miyoshi 2003. Narratives of Nation Building in Korea. A Genealogy of Patriotism. Armonk, New York and London: M. E. Sharpe. 
Pride and Prejudice in South Korea's Foreign Policy

Kim, Byung-Kook 2003. 'The US-South Korean Alliance: Anti-American Challenges.' Journal of East Asian Studies 3(2): 225-58.

Kim, C. I. Eugene and Han-Kyo Kirn 1967. Korea and the Politics of Imperialism 1876-1910. Berkeley and Los Angeles: University of California Press.

Kim, Hybn-Mi 2003. "'386" 7 nybn. Ybjbnhan chbnwi pudae, ktirbna churyu kkumkkuntin p'awbmaendtil' ['386', the 7th year. The Powermen, Frontline Troops as Before, but Dreaming of the Mainstream]. Sindong a (December):204-15.

Kim, Hyuk-Rae 2004. 'The Paradox of Social Governance: State, Civil Society, NGO's in South Korean Reform Politics.' Korea Observer 35(3): 417-32.

Kim, Jai-Hyup 1978. The Garrison State in Pre-War Japanand Post-War Korea: A Comparative Analysis of Military Politics. Washington, DC: University Press of America.

Kim, Key-Hiuk 1980. The Last Phase of the East A sian World Order. Korea, Japan and the Chinese Empire 1860-1882. Berkeley and Los Angeles: University of California Press.

Kim, Pang-Hiii 2003. 'Ch'amybchbngbu "chuyǒk" 386 ybn'gu' [AStudy on the 'Leaders' of the Participatory Government, the 386ers]. Sindonga (July)(consulted online).

Kim, Sun-Hyuk 2002. 'Civil Society and Democratization.' In Charles K. Armstrong (ed.), Korean Society. Civil Society, Democracy and the State. London and New York: Routledge: 92-108.

- 2003. 'Civil Society in Democratizing Korea.' In Samuel S. Kirn (ed.), Korea's Democratization. Cambridge: Cambridge University Press: 81-106.

Moon, Chung-in and Taehwan Kirn 2004. 'South Korea's International Relations: Challenges to Developmental Realism?' In Samuel S. Kirn (ed.), The International Relations of Northeast Asia. Lanham, Boulder, New York and Oxford: Rowman \& Littlefield: 251-79.

Na, Jeong-Ju 2004. 'Massive Anti-Impeachment Rallies Planned Saturday.' The Korea Times, 19 March (consulted online).

Na, Sbn-Mi 2005. '[386-Chongch'i tiisik ybron chosa] 386-sedae oegyo-ntin chinbo, naejbng-tin posu' ([The 386 Political Consciousness Survey] The 386 Generation; Progressive in Foreign Policy, Conservative in Domestic Policy).Tong a Ilbo, 2 January (consulted online).

Oberdorfer, Don 1997. The Tzuo Koreas. A Contemporary History. London: Little, Brown \& Co.

Oh, John Kie-Chiang 1999. Korean Politics. The Quest for Democratization and Economic Development. Ithaca and London: Cornell University Press.

O'Hanlon, Michael and Mike Mochizuki 2003. Crisis on the Korean Peninsula. How to Deal with a Nuclear North Korea. New York: McGraw-Hill.

Pak, Ch'bl-Htii 2005. 'Ilbon shinbangwi kyehoek taegang-iii p'ybngga' (An Appraisal of Japan's New Defence Plan Outline). In Chuyo kukche munje punsŏk 26 January (consulted online).

Palais, James1991. Politics and Policy in Traditional Korea. Harvard: Harvard University Press.

Park, Chung Hee 1971. To Build a Nation. Washington, DC: Acropolis Books.

Saxer, Carl J.2002. From Transition to Pozuer Alternation. Democracy in South Korea, 19871997. New York and London: Routledge.

- 2003. "'A Generational Earthquake"? An Analysis of the 2002 Presidential Election in South Korea.' Copenhagen Journal of Asian Studies 18: 23-39.

Shin, Gi-Wook and Kyung Moon-Hwang (eds) 2003. Contentious Kwangiu. The May 18 Uprising in Korea's Past and Present. Lanham, Boulder, New York and Oxford: Rowman \& Littlefield.

Shin, Myung-Soon 2004. 'Changing Elite-Mass Relations in Democratizing Korea.' Korea Observer 35(1): 1-22. 
Koen De Ceuster

Sigal, Leon V.1998. Disarming Strangers. Nuclear Diplomacy with North Korea. Princeton: Princeton University Press.

Stueck, William 1995. The Korean War. An International History. Princeton: Princeton University Press.

- 2002. Rethinking the Korean War. A New Diplomatic and Strategic History. Princeton and Oxford: Princeton University Press.

Wells, Kenneth M. 1990. Nezv God, Nezv Nation. Protestants and Self-Reconstruction Nationalism in Korea 1896-1937. Sydney: Allen \& Unwin.

Wit, Joel S., Daniel B. Poneman and Robert L. Gallucci 2004. Going Critical. The First North Korean Nuclear Crisis. Washington, DC: Brookings Institution Press.

Woo, Jung-En 1991. Race to the Swift. State and Finance in Korean Industrialization. New York and Oxford: Colombia University Press.

Yi, Sd-Hang 2005. ARF-ŭi Palchŏn panghyang: Tongasia Taja anbo Hyŏpnyŏkch'e Silt'ae punsŏk-kwa Kwallyŏn hayŏ [The Direction of ARF's Development; in Relation with the Analysis of the State of Multilateral Security Co-operation Structures in East Asia]. Seoul: Oeguk anbo ybn'guwbn (consulted online).

Yun, Tbk-Min 2005. Han'guk-ŭi chŏllyakchŏk sŏnt'aek: tongmaeng, chaju, taja anbo [Korea's Strategic Choices: Alliance, Autonomy, Multilateral Security]. Seoul: Oeguk anbo ydn'guwdn (consulted online). 